\title{
Women Empowerment in Tourism: Special Reference to Pokhara Metropolitan City
}

\author{
Amin Palikhe* \\ Received on 12 September 2018; Revised on 1 November 2018; Accepted on 4 December 2018
}

\begin{abstract}
This article examines women empowerment in tourism with reference to the Pokhara Metropolitan City, Nepal. The major objective is to identify the women in tourism, their situation, problem, and obstacle and future perspective in the tourism industry. The descriptive and analytical research design is used. Primary and secondary sources of data are used. Fifty-two samples have been taken from the tourism industry (hotel, lodge, travel, and trekking) and a questionnaire distributed to women. Some women are entrepreneurs and some are employees in the tourism field in Pokhara. Women are gradually being motivated to involve themselves in tourism-related business. These days, women's contribution does not equate males when they are compared. Most of the women work at a lower level and they are satisfied with their work and their contribution. Women face different obstacles that hamper them to move, initiate and run their business. Women have better potentiality in different tourism sectors like direct and indirect, such as framing, planting, travel, and trekking, rural tourism, home stay, medication, and hospitability. But they have various causes and reasons to work at a lower level.
\end{abstract}

Keywords: Empowerment opportunity, participation, tourism, women

\section{INTRODUCTION}

Tourism is one of the fastest growing and most competitive industries in the world. It should be marketed, just like any other product, indeed more so, because it is an industry in which the customer still has an immense variety of choice. There are a number of destinations competing with each other to get a bigger and bigger share of the market. Hence, tourism marketing is regarded as a central point of whole tourism activities (Shrestha, 1997). It is a multifaceted action and it requires various services from the starting to endpoint location of the diverse area of different in nature and complex countries (Sinha, 1998). Seven percent of the total global investment falls in this sector and it contributes 13 percent to the global GDP. This industry engages about more than 10.6 percent of the global workforce (Bharadwaj, 2006). Tourism is acting as a vibrant part in the economy of both the developed and developing countries. Tourism has become one of the important segments of the Nepalese economy after the National Development Plan highlighted the importance of this sector in 1972. Now, it has grown into one of the most important industries of Nepal and an effective tool for promoting economic growth (Gautam, 2008).

History of women's working condition in Nepal was liable to perform domestic activities, but now the

* Mr. Palikhe is Lecturer in Faculty of Management, Prithvi Narayan Campus, TU, Pokhara.

E-mail:amin@pncampus.edu.np 
figure has drastically changed because they are involved in different business activities including tourism. They have revised the status and condition of them with their family by engaging in different earning activities. This movement brings and reduces gender discrimination and inequality in employment. Even though, their work remains disregarded. They have failed to perform both roles in and outside of their life. The report clearly shows that Nepal is still male dominating society because most of the time males could do outstanding than women in the different form of paying treatment. This is also a truth very often seen and felt in Nepal (KC, 2012). Data shows that one tourist employs nine persons directly and indirectly. Women are also actively moved in various facets of this industry. Tourism expands day by day and has become an industry with high potential. Since tourism is a warmth industry, and involvement and participation of women in tourism have a significant impact on the growth of the tourism industry. Women's engagement is necessary for every part of the tourism business and the tendency is also increasing at the present time. According to the World Tourism Organization, since the mid the 70s their partaking roles women are tremendously increasing in tourism business (MOT/UNDP, 2006).

None other than the mountain tour was the first opportunity for the women in the tourism activities and it was started in the 1920s, now women are leading trekking business in Nepal. Regarding the comparison of gender perspective, women are still in limited number and toddler stage in trekking business activities. In mountain tourism also there is a limited prospect for women in the indirect sector like tea, small shop, farming and so on. The opportunities open for women on mountain tourism are mostly concentrated in urban mountain areas like Kathmandu and Pokhara as well as on popular trekking routes in the Annapurna and Everest regions. Women workers in mountain tourism are comparatively in large numbers of an unskilled and illiterate worker at informal sector like tea shops, small lodges (Gurung, 1995). Women's roles and responsibilities are undermined as outranked to men due to twin responsibilities and workload, weak decision making power, lack of government rules and regulation, physical problem, presenting women as subgroups of the family can be explained as prominent reasons behind the contribution of women in this sector. Even though development plan (1992-1997) of Nepal documented the required important skill, education and training for women to enhance and increase their participation in tourism there has been just 10.2 percent of women actively participating in tourism sectors as direct involvement. Therefore, the government of Nepal has strongly touched and directed the national policy to encourage and increase the need for women's participation in the tourism sector. Besides this, a limited number of women participates in managing hotel or lodges along with trekking when compared to men. Those who involved in the lower level jobs belonged to porters, and labors, housekeeping, cooking, and other basic jobs. The findings show that there are comparatively larger numbers of women workforce in the informal sector like tea shops, lodges, guest houses (Upadhaya \& Upreti, 2008). Thus, the main purpose of the present study is to assess the women in the tourism sector in Pokhara. Unless and until the basic situations are identified and analyzed, the efforts to develop tourism would be ineffective. Therefore, these issues need to be understood, though detail information research and studies. The extensive study is desired in order to establish tourism as one of the most promising and prosperous sectors of Pokhara as well as Nepalese economy. In this perspective, a series of questions may be raised such as, how many women are involved in this sector? In which area and sector-direct or indirect, are more women involved? What is their condition as compared to their male counterparts? 


\section{LITERATURE REVIEW}

Wilkinson and Pratiwi (1995) examined gender roles in tourism through a case study on gender and tourism in an Indonesia village. They explored that tourism is emerging opportunities field for women for employment in the inner field of tourism-related activities besides that both women and men have a greater occupational choice and different level of gender mix can have employment access and opportunities in Bali. Additionally, women require greater qualification in the formal sector and receive less remuneration in similar types of position. Women must balance the religious matter inside and outside the home.

Upadhya and Upreti (2008) conducted research with the objective of analyzing the participation of women in the field of mountain tourism in Nepal. They identified that women's participation in mountain tourism started during the 19th century and got a specific stage in this field to operate different tourism businesses hotels, lodges, restaurants, trekking and travel agencies and some of the women have been reached in the top management level. However, the majority of their involvements are at lower level jobs in variously organized sub-sectors of tourism. They focus on the formulation of safeguard and protective measures to access, upgrade and benefits to a smaller number of participation and lower level of engagement in tourism sectors. These counterparts help to social transformation in mountain tourism.

Shakeela, Ruhanen, and Breakey (2010) found that Maldivian women are more opened and key participants in the tourism market in South Asia and Islamic countries. Socio-demographically there is no gender discrimination regarding access in different services. Nevertheless, the share of women working in the Maldivian tourism industry is relatively low. This discovers one of the important situations regarding the involvement of women in the tourism industry. Government plays an important role in balancing forcefully all factors that directly related to the involvement and participation of women in the tourism market.

Women are found around half of the total world population. They perform around the four walls of household in traditional times but now they came out and cross out those four walls to engage in different sectors of economic activities, among them one is tourism. In general, tourism denotes the movement or journey of human beings from one place to another whether it may be within own country or other countries for various purposes. The word tourism so popular today, was derived from its French word "Tourisme", which originated in the nineteen century. Later this word was popularized in the decade of 1990s but its significance is not fully realized until today when tourism has wider meaning and significance (Styal, 1990).

The term empowerment refers to measures designed to increase the degree of autonomy and selfdetermination in people and in communities in order to enable them to represent their interests in a responsible and self-determined way, acting on their own authority. It is the process of becoming stronger and more confident, especially in controlling one's life and claiming one's rights. Empowerment as action refers both to the process of self-empowerment and to professional support of people, which enables them to overcome their sense of powerlessness and lack of influence and to recognize and use their resources. To do work with power. Empowerment as a concept, which is characterized by a move away from a deficit-oriented towards a more strength-oriented perception, can increasingly be found in management concepts, as well as in the areas of continuing education and self-help. 


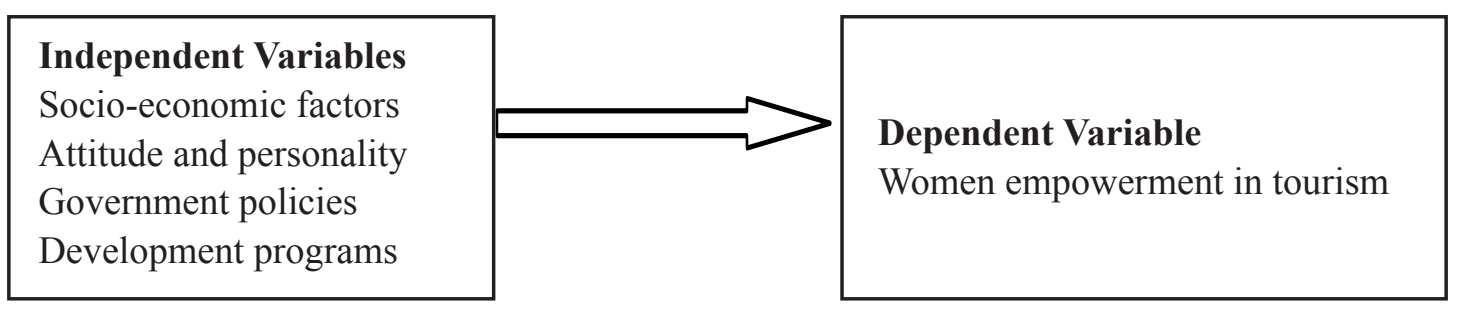

Figure 1. Conceptual framework

Figure 1 explains the dependent and independent variables where socio-economic factors, attitude and personality, government policies and various development programs are an independent variable that may affect the engagement of women in the tourism sector. Therefore, women empowerment is directly affected by these independent factors.

\section{DATA AND METHODS}

In this research, women are selected because women still do not consider as a study area in tourism. To make the research acceptable, tourism business related women entrepreneur and worker are selected to find out real situation and the problem of women in tourism. The women empowerment is a dependent variable whereas socio-cultural factors, government policies, development program, attitude and personality of those independent factors can affect in the empowerment of women in the tourism field. The descriptive and analytical research design is used to describe the attitude and behavior of the women worker in the field of tourism. Therefore secondary data is used. The quantitative research method is used to identify the actual engagement type of work, cause, selection criteria in tourism. The tourism industry is the population of this study. For the study, 52 respondents have been selected as the sample units from the tourism industry (hotels and lodges, restaurant and travel and trekking agencies). A purposive sampling method is used because of identifying the real situation and problem of women's engagement in the tourism sector. The required data is collected from using a close and open-ended questionnaire to tourism workers in restaurant, hotels, travel, and trekking, and money changer as well. Therefore, primary sources are used as a questionnaire. The primary and secondary data were categorized, tabulated, processed, analyzed and computed by descriptive analysis. The response data were analyzed through SPSS program. Ethical consideration is applied through administering, explaining and creating confidentiality of responses of the women worker.

\section{RESULTS AND DISCUSSION}

This article inspects the genuine problem of women in the engagement of tourism sectors along with identifying and analyzing the status, position, perception of women and so on. The demographic character, the situation of women, motivation and future perspective of women in this business are analyzed and presented to focus further on the encouragement and empowerment of tourism for women.

\subsection{Demographic Characteristics}

It is essential to know some demographic and socio-economic characteristics of the worker. This topic mainly deals with some important demographic characteristics such as age, marital status, family size etc. It also provides an analysis of socio-economic characteristics such as income level and other 
economic characteristics of the respondents. This section deals with some selected socio-economic indicators of worker such as family size, income, religion, caste/ethnicity etc.

Table 1

Demographic Characteristics of Women in Tourism Sector

\begin{tabular}{|c|c|}
\hline Factors & Percentage \\
\hline \multicolumn{2}{|l|}{ Age Group } \\
\hline 0 to 19 & 22.0 \\
\hline 20 to 29 & 48.0 \\
\hline 30 and above & 30.0 \\
\hline \multicolumn{2}{|l|}{ District } \\
\hline Kaski & 65.4 \\
\hline Others & 34.6 \\
\hline \multicolumn{2}{|l|}{ Position in the family } \\
\hline First person & 44.2 \\
\hline Second and other & 55.8 \\
\hline \multicolumn{2}{|l|}{ Marital status } \\
\hline Married & 53.80 \\
\hline Unmarried & 46.20 \\
\hline \multicolumn{2}{|l|}{ Family size } \\
\hline 1 to 5 & 69.2 \\
\hline 6 to 9 & 28.8 \\
\hline 10 to 14 & 1.9 \\
\hline \multicolumn{2}{|l|}{ Ethnicity/Caste } \\
\hline Brahmin/Chhetri & 48.0 \\
\hline Janajati /Hill & 38.50 \\
\hline Dalit & 7.70 \\
\hline \multicolumn{2}{|l|}{ Religion-wise } \\
\hline Hindu & 84.6 \\
\hline Buddhist & 9.6 \\
\hline Christian & 5.8 \\
\hline \multicolumn{2}{|c|}{ The income level of employee (monthly) } \\
\hline Rs 0 to 4999 & 58.80 \\
\hline Rs. 5000 to 9999 & 35.30 \\
\hline Rs. 10000 and Above & 5.90 \\
\hline
\end{tabular}

Source: Field survey, 2016

A description of the background characteristics of the worker age is 15-49. Table 1 reveals that involvement of women employees' in tourism falls in the age group of 20 to 29 and it is maximum than other groups which are evident in the Kaski district rather than other. Others are the district from Tanahu, Syanja, Parbat, etc. Most of the women are the second child of the family in the tourism sector 
as workers. It reveals that among worker of age 19 to 40 plus, the unmarried was 46.2 percent, whereas 53.80 percent majority of workers are married. Nature of family is one of the most important factors for analyzing the characteristics of the study respondents. Women workers, who are involved in this sector, have a maximum number of families up to five people's family. Among the various social characteristics of respondents, ethnic composition is a major component which directly affects in knowledge, attitude, behaviors, and status and in many more elements of life. During the survey period, the respondents are the composition of different ethnic groups like Brahmin, Gurung, Chhetri, Magar, Newar, Damai, etc. These were classified into four groups. As workers in the tourism sector for women are maximum form the Brahmin or Chhetri cast followed by Hill or Janajati group. There are different types of religious such as Hindu, Buddhist, etc. Income is another factor which reflects the socio-economic status of a person. They earn a maximum of five thousand from the involvement in this sector.

\subsection{Women's' Place in Tourism}

Due to the immense amount of educational skills, women have been coming out from their kitchen activities 3 P's: Pickles, Powder and Pappad to 3 modern Es, viz, Engineering, Electronics, and Energy. They also participate in dynamics, skillful and adventurous business. The tourism policy of Nepal has given a different dimension to the tourism industries. Women, directly and indirectly, involved in those sectors their involvement is noticed and remembered by people. There is also the potential involvement of women in other business which is directly related to tourism. Data collected from Pokhara Tourism Office shows that nearly to 15 percent women entrepreneurs are involved in the tourism sector (a year from 2041 to 2073 ) in areas like a registered hotel, restaurant, and travel, and trekking. It might be varied depending upon the data sources and different data available in the office. The available information also reveals that women involved in this industry of Nepal get less benefit.

Women are working in the lower hierarchical positions as unskilled and semiskilled workers more.

Table 2

Employment Situation of Women in Tourism

\begin{tabular}{ll}
\hline Women' proprietorship & Percent \\
\hline Hotel, lodge, and resort & 33.87 \\
Travel and trekking & 36.74 \\
Others & 29.39 \\
\hline The working situation of an employee & 21.2 \\
\hline Sweeper & 1.9 \\
Dancer & 15.4 \\
Manager & 61.5 \\
Waiters & \\
\hline Working hours of employee & 40.4 \\
\hline 8 & 44.2 \\
10 & 15.4 \\
12 & \\
\hline Staff in a business firm & 81.25 \\
\hline More male & 12.50 \\
More female & 6.25 \\
\hline
\end{tabular}


They function as behind the screen actors and as a result, 86 percent of them have less than Rs 5000 as monthly income. in many cases, the income benefit obtained from women's labor in tourism is neither acknowledged nor accounted. Table 2 reveals that out of the total self-employed women in tourism sector, nearly 71 percent owned hotel, lodge, resort, travel and trekking agencies. Also, the maximum numbers of workers involved in the work waiters'.Generally, a worker works almost ten to twelve hours in this sector for serving the customer. 81. 25 percent of business has more male employees than female, whereas only limited percent indicates the low involvement of women in the tourism field as an employee.

\subsection{Reason and Causes of Women in Tourism}

Because of different social, attitudinal, institutional, financial, economic, political and legal obstacles women are far from men in tourism activities. Gender differences influences and plays a great role in the low involvement of women on one side and on the other way women 's social and physical circumstances can create the problem in continual work of given jobs. Such behaviors and attitude of the employers regarding women may be due to the discriminating nature of the male-controlled society. Definitely, women lack in capital assets, resources, rights to invest, education, appropriate and adequate skill, and training, confidence to take decisions and lack risk taking capacity and so on. The narrow social thought prevails the women in and around the house and the community than involved in dynamic work like an adventurous business like trekking and other business. Lack of agility and lack of disclosure, lack confidence force to take women late in markets transactions and sometimes negative behavior and attitudes of the society and the family members creates obstacles for harnessing a woman's involvement in tourism activity. Besides, they have less confidence for the legal right of resources and household assets and so have little political/legal positions with the knowledge of appropriate policies and laws. Table 3 identifies some causes and problems related to women in tourism.

Table 3

Reason and Causes of Women in Tourism

\begin{tabular}{lc}
\hline \multicolumn{1}{c}{ Factors } & Percentage \\
\hline Cause of joining the work & 50.0 \\
\hline Earn money & 1.9 \\
Conflict & 5.8 \\
Leave home & 1.9 \\
Uneducated & 25.0 \\
Freedom to live & 15.4 \\
Other causes & \\
\hline Causes of involvement & 31.25 \\
\hline Earn money & 37.50 \\
Freedom to live & 31.25 \\
Other reason & 48.1 \\
\hline Causes of selection of work & 13.5 \\
\hline Easy work & 3.8 \\
Good salary & 11.5 \\
Transportation facility & 23.1 \\
Accommodation facility & Source: Field survey.2016 \\
Others & \\
\hline
\end{tabular}


A worker in the tourism sector especially joins for earning of money for the family whereas 25.0 percent looks to stand on own foot. There is a positive response of the owner towards the involvement of women employee in the tourism sector as employees. Table 3 shows that women need money to operate their family and so they involve in this sector to earn money and works almost ten to twelve hours in this sector to just earn five thousand below.

\subsection{Women's Motivation Towards Tourism Industry}

Women's engagement and participation in the tourism sector has been increased directly and indirectly in the tourism industry (Khanka, 2007). Data collected from Pokhara Tourism Office, Pokhara shows those 14.72 percent of women entrepreneurs are involved in the tourism sector among hotel, restaurant, and travel and trekking as an entrepreneur or as an employee. Various projects are launched by Nepal government with financial assistance from the UNDP/ILO to develop women's entrepreneurship skill and equip them to use the available opportunity in the field of tourism. This act paves the way to explore women's potential in the tourism sector and give emphasis to women's participation to improve the situation of women in tourism (Upadhaya, 2008).

Realizing that sustainable development of the dynamic business like tourism is not possible unless and until women do not participate and benefit from it, the program seeks to increase sustainable involvement of women. The program aimed to involve more women in tourism by encouraging women to establish different tourism-related enterprises like handicraft, cultural dances, and hospitality services. It has also initiated the poor women to become leaders in their society by empowering them. The program also aims at improving women's condition, position and capacity level in the tourism business that includes training content in different physical, psychological and social problems that women face in the society, their root causes and probable of remedies of the problems (MoT/UNDP,2006). Different NGOs and INGOs like UNDP, GTZ, WWF, ICIMOD, SWATI, and SAATHI provide training and other essential support to women to take up what was considered as man's job. This is a way and help proves that women could work on equal footing with men. In this sense, it can be said that women are capable enough to hold any responsibility like their male counterparts and there is no dearth of employment for capable women in tourism if provided right training, education, and support (Khadka, 2008). Table 4 explains the possibility of women's empowerment, encouragement and their satisfaction in the tourism sector.

Table 4

Motivation towards Tourism Sectors

\begin{tabular}{lc}
\hline Factors & Percent \\
\hline The opportunity to work available & \\
\hline Self & 48.1 \\
Friend & 19.2 \\
Relative & 28.8 \\
Others & 3.8 \\
\hline Level of satisfaction & 88.5 \\
\hline Yes & 11.5 \\
No & Source: Field survey, 2016 \\
\hline &
\end{tabular}


Most of the women employees join in this sector as an employee by their own effort whereas 28.8 percent search the job with the help of their friends. The workers attain satisfaction in this job due to the problem of availability of vacancies in other sectors and the level of income. It seems that women are encouraged to join in this sector of business since there are more vacancies available in the field.

\subsection{Future Perspective of Women's Potentiality in the Tourism Industry}

Nepal is a popular tourist destination all over the world. It can attract those people who love nature, environment, culture, indigenous society, harmonious people besides conservation, monasteries, sanctuary including great hospitability. This is not only in the case of all areas in Nepal but also in Pokhara that serves huge potentiality of tourism activities second to the Kathmandu valley. In offering great hospitality services to visitors' women play a significant role in this sector directly in conservation, protection, and management of the natural resources. They also have huge local indigenous knowledge and experience about the nature of their locality and therefore, they can provide proper which provides directorial, demonstrating, facilitating and providing hospitality for tourists about tourism product which tourist wants to see in this great valley of hospitability.

Pokhara can serve a great variety of needs by tourist those who want to come for any purpose. Particularly women can be used in tourism for future prospective like demonstration of cultural, indigenous, rural and village areas including home stay, cultural experience and mela, operating lodge, cleaning, porter, plugging milk, plantation practices, cooking and serving, trekking and traveling even rafting and other adventurous field that women can experience and actively involved. Through these women, tourists take part in those activities and get the opportunity to share the ideas with the local people involved in farming, learn about rural agriculture, traditional technology, culture, rural lifestyle, etc. Therefore religious and cultural program can be helpful for women to get involved in all kinds of activities. These types of services are much needed for tourism to give an opportunity for women. Besides that festivals, ceremonies, events and jatras like Ganesh Jatra, Gaijatra, Holy, Krishna Janmashtami, etc. motivates the tourist and women can play an important role in these festivals and event present perfectly to the guest. Their participation in these activities provides plenty of opportunities of employing them and justifies their potentiality in cultural and religious tourism. Furthermore, women's self-confidence also increase. The Three Sisters' Adventure Trekking (first women trekking business) is the example that shows, there are brave Nepali women who can do a lot for themselves and for Nepal's tourism development.

\section{CONCLUSION}

Many Nepalese women have the capacity to handle businesses on indigenous products such as handicrafts, garments, ornaments, floriculture etc, which are the strong side of income generation activity associated with tourism. There is a huge possibility of utilization of local and traditional skills and resources for encouragement, empowerment and women participation in small enterprises. Women's indigenous or traditional skills and handicraft skills of women should be used to make tourists oriented products and services that could improve as professionalism by providing a good opportunity for economic empowerment of women. Therefore, government agencies, NGOs and INGOs including social organization have to organize women empowerment and development program. Even though, there is just 14.72 percent of women are engaging in a major tourism-related business like hotel, travel 
and trekking and restaurant. Women need opportunities, resources, and accessibility in parts of life for the empowerment of women in the tourism field. Different religious and cultural program, traditional festival and activities like Ganesh Jatra, Gaijatra, Holy, Krishna Janmashtami, Asare Pandora, and many more such activities are properly performed and operated by women. Such things enhance women's opportunities and role in tourism sectors. Therefore, social communities empower to plan and organize those festivals. However, women's traditional role may overload them. More study regarding the tourism and tourism-related industries should be carried out without gender perspective and offer training and education to empower women in tourism. There is no mention of gender perspective in tourism policy of Nepal, therefore, it is recommended necessarily to formulate such policies to enhance women empowerment towards the tourism and to have equitable benefits of tourism-related activities. There is important to increase public awareness of the interrelation between tourism and its beneficial role for women. The changing social perspective and the environment should be favorable for the changing role of women to involve and sustain in tourism. For this man should cooperate with women in their special condition like menstruation, pregnancy situation.

\section{REFERENCES}

Bharadwaj, D. S. (2006). International tourism: Issues and challenges. New Delhi: Kaniska Publishers.

Gautam, B. P. (2008). Tourism in Nepal: Emerging issues in Nepal, Working Paper. Kathmandu: Ministry of Tourism/ Nepal Academy of Tourism and Hotel Management.

Gurung, D. (1995). Tourism and gender, impacts and implication of tourism on Nepalese women, Discussion Paper Series No.MEI 95/3, Kathmandu: ICIMOD.

K. C. Tilak. (2000). Migration and its consequences on tourism with special reference to Fewa Lakeside. Janapragyamanch, 1(1),155-157.

Khadka, B. (2008). Some thoughts on tourism in Nepal in the vision-2008. Kathmandu: BVC.

Khanka, S. S. (2007). Entrepreneurial development. Delhi: Sultan Chand and Sons.

MOT/UNDP. (2006). Gender equity, women's health and HIV\&AIDS orientation for pro- women rural tourism development. Kathmandu: MOT/UNDP

Satyal, Y. R. (2000). Tourism monograph of Nepal. Delhi: Abroit Publishers.

Shakeela, A., Ruhanen, L., \& Breakey, N. (2010). Women's participation in tourism: A case from the Maldives. In N. Scott, \& J. Jafari (Eds.), Tourism in the Muslim world: Bridging tourism theory and practice (pp. 61-71). Retrieved from http://www. repository.usp.ac.fj/ 8699/1/ BkChptr_Tourism_Muslim_World.pdf

Shrestha, P. (1997). Tourism in Nepal: Problem and prospects (Unpublished doctoral dissertation), Department of Economics, Faculty of Social Science, Banaras Hindu University.

Sinha, R. K. (1998). Travel and tourism management. Delhi: Dominant Publisher and Distributors.

Upadhaya, R.P. (2008). Rural tourism to create equitable and growing economy in Nepal. Kathmandu: Nepal Academy of Tourism and Hotel Management.

Upadhya, P. K., \& Upreti, B. R.(2008). Enhancing women's participation in mountain tourism: Prospects and challenges. Mountain Forum. Retrieved from http://lib.icimod.org/record/13555/files/1265.pdf

Wilkinson, F. P., \& Pratiwi, W. (1995). Gender and tourism in an Indonesia village. Annals of Tourism Research, 22(2), 283-299. 